Sign Systems Studies 49(1/2), 2021, 235-261

\title{
The dialogic nature of double consciousness and double stimulation: Implications from Peirce and Vygotsky
}

\author{
Donna E. West ${ }^{1}$
}

\begin{abstract}
The objective in this paper is to demonstrate the indispensability of Peirce's double consciousness to foster abductive reasoning, so that internal/external dialogue inform the worthiness of hunches. These forms of dialogue establish a mental give-and-take forum in which novel meanings/effects are particularly highlighted and noticed. Such attentional shifts are compelled by surprising states of affairs within the beholder's internal, interpretive competencies, or from external factors (pictures, gestural or linguistic performatives). The dialogic nature of these signs pre-forms operations not possible non-dialogically; they command, interrogate, or suggest alterations to established conduct/beliefs in contexts in which propositional/argumentative conflicts are obviated.

This inquiry proposes experimental methodologies to measure when double consciousness (via private/inner speech) mediates hypothesis-making. Vygotsky's conflict of motive at four distinct developmental stages constitutes the foundation for the proposed experiments. Designs draw upon Vygotsky's 'double stimulation' paradigms that force decision-making processes when conflicts of motive surface. Paradigms include forced imitation of one model while ignoring another (imitating bear, not dragon), and altering a visual array to depict logical sequencing accurately (the "Cycles Test"; "The Odd One Out"). These conflicts require children to change their conduct/beliefs to accommodate to atypical states of affairs.
\end{abstract}

Keywords: surprise; double consciousness; double stimulation; conflict of motive; testing paradigms

\section{Introduction}

The present inquiry compares the role of dialogic thought in the semiotic models of Charles S. Peirce and Lev S. Vygotsky. The inquiry demonstrates that Peirce's dialogic concept of double consciousness informs Vygotsky's double stimulation

1 State University of New York at Cortland, New York, USA; e-mail: Donna.West@cortland.edu. 
method of testing by providing a clear rationale for the necessity of surprise in the struggle of how to address new versus old facts. Peirce advocates that apprehending facts in a spontaneous and dialogic fashion constitutes the primary path for introducing new information. For Peirce, the insistence of the new information constitutes a formidable forum toward furthering inquiry through all modes of experience, phenomenal and otherwise: "It is by surprises that experience teaches all she deigns to teach us" (EP2: 154, 1903; CP 5.51). In fact, Peirce advocates that it is the two-sided opposition enlightened by surprise which penetrates into the truth value and underlying explications supporting already held belief/fact habits which must be reconciled with propositions insinuated in the new information. This dialogic forum unquestionably brings forth a most focused form of inquiry, which introduces new ways of explaining facts; as such, it temporarily creates a divided world which highlights conflictual features of suddenly noticed information often contrasted with the interpreter's assertions (cf. CP 8.282; Cooke 2012: 186).

In the Neglected Argument, Peirce affirms surprise as a central inciter (universally) to trigger inquiry: "Every inquiry whatsoever takes its rise in the observation, in one or another of three universes, of some surprising phenomenon, some experience which either disappoints an expectation, or breaks in upon some habit [...]" (EP2: 440). New facts within dialogic considerations either "disappoint expectations" or "break in upon habits"; and when the difference emerges as a viable option, a change in habit is often evoked. This change need not rise to conscious belief alterations; instead, the change may take the form of more unconscious reactions (devoid of a clear plan), e.g., withdrawing from passive entertainment. It is obvious that dialogic processes possess the internal efficacy to establish and maintain oppositional issues; and the conflict/war between new and previously held assertions is ultimately resolved, for Peirce, in new action-habits (cf. Stjernfelt 2014: 118); otherwise the habits would be virtual only, within minds (Bergman 2016; West 2017). These new courses of action (habits) are impelled by retroductions conceived from the surprising facts (cf. EP2: 231) which are gleaned during dialogic interactions. In line with Peirce's pragmatistic purpose, these new action-habits spring from surprises in dialogic exchanges and from the reasoning which they furnish. The result is what Peirce refers to as "practical, [...], and scientific retroductions" (abductions) which "recommend a course of action" (cf. MS 637: 12). In short, Peirce is convinced that surprise gives rise to new practical habits - as actualized courses of action in Secondness.

Nonetheless, it must be recognized that Peirce's emphasis on dialogic processes (particularly those obviated in double consciousness) in the acquisition of new facts and new habits is not dyadic, but triadic (cf. Colapietro 2015). Dialogic processes of back-and-forth scrutiny of facts following surprise are virtually always 
compelled by the purposes which the practical consequences furnish. Achieving a particular purpose is at the centre of conceiving of and actualizing new courses of action. Thirdness-based objectives are primary. In fact, were purpose not in view from the very outset of the dialogic process, conception and implementation of action-habits (exacted during inferencing) might never materialize. This prerequisite state of seeking purpose constitutes a readiness to apprehend initially another's fact interpretations, as well as making sense of conflicts arising within the inquirer's own mind; and Thirdness becomes an agent for reforming and settling upon more workable reactions. In short, Peirce's dialogic approach to promote inquiry supports his entire semiotic, because the will to utilize non-egobased sources to inform hunches and to test them secures the integrity of signs. Apprehending new facts (from non-ego challenges) supplants old interpretations. As such, conflicts created by surprising consequences are converted into different habits, highlighting the indispensability of dialogic inquiry to ensure that sign meanings are dynamic. Oppositions between facts force novel determinations new facts which then question previously held facts.

It is in these internal dialogues that the possibility of new renditions of fact and their effects demonstrates the influence of Thirdness upon propositions emanating from phenomenal sources. Vygotsky's contribution to dialogic rationality is far from insignificant. In developing experimental measures to facilitate attentional control and conflictual resolution, Vygotsky and his colleagues offer experimental paradigms to measure the effects of single decisions and resultant reactions. Yet the paradigms fail to account for the underlying inferential process (packaged in Peirce's double consciousness) which is responsible for the reciprocal process of changing and settling upon reactions. Although they trace changes to stimuli at different stages in development, their paradigms are contrived; and they force children to make immediate decisions, which often lack real meaning.

\section{Vygotskian double stimulation}

Vygotsky's concept of 'double stimulation'2 derives from Leont'ev's experimental method (Leont'ev 1932: 76); the objective in this experimental design is to measure and even hasten mediated attentional processes (cf. Vygotsky 1997[1931]: 154-155). Despite the absence of evidence that either investigator was familiar with Peirce's notion of double consciousness, the utility to measure the onset and complexity of double consciousness is formidable. Vygotsky's and Leont'ev's

2 For further foundation on double stimulation, cf. Engeström 2007. 
experiments attempt to measure when children (ages ranging from $2 ; 0^{3}$ until approximately early adulthood) begin to recognize conflicts between their own strongly held assumptions, and what conditions militate in favour of changing habits of belief/conduct. These investigators' intent was to create sufficient semiotic discord between signs and their objects that younger children begin to question previously held propositions. They attempt to create the semiotic discord by separating them from their own idiosyncratic attentional forces. The process for younger children is to permit them to apply a conventional sign or to engage in an ordinarily performed behaviour only in the condition which the experimenter selects. This requirement has the advantage of regulating/controlling attentional focus, which eventually enhances children's deliberative awareness of conduct beyond verbatim/automatic responses:

Now let us consider very briefly one complex phenomenon that is not clear in subjective analysis and which is termed the experience of exertion. Where does it originate in voluntary attention? It seems to us that it flows from the additional complex activity that we term control of attention. It is completely natural that this exertion is absent where the mechanism of attention begins to work automatically. Here we have additional processes, we have conflict and struggle, we have an attempt to direct the processes of attention along other lines, and it would be a miracle if all of this could be accomplished without exertion, without serious internal work on the part of the subject, work that can be measured by resistance met by voluntary attention. (Vygotsky 1997[1931]: 160)

The purpose of this self-controlling mechanism is to have subjects utilize neutral stimuli to motivate their exertion toward a goal (ordinarily practical) - the will to act/believe in a different way. Forcing exertions within the paradigm of attentional control hastens conscious attention to the existence of different and often contrasting meanings/effects. These effects are held by interlocutors to associate signs, their meanings, and their objects - to such a degree that double meanings become obviated. The intent of Vygotsky's double stimulation paradigm was to force children to determine consciously the rationale for when and why different responses in distinct scenarios were sought after (cf. Zavershneva 2014). Although Vygotsky intended to develop paradigms to measure what he referred to as "conflict of motive" (Vygotsky 1997[1930]: 167-168), motives for older children were less attention-based (automatic) and more affective. Their purpose was not to dissociate linguistic signs (legisigns) from their meanings and objects, but rather to charge subjects to associate two different effects/meanings with indexical signs.

3 Child ages are represented by a " $x ; y$ " notation, indicating the year and month, separated by a semicolon in keeping with the conventions within developmental psychology. 
The conflict of motive expected in these latter paradigms was affective discomfort/ moral dissonance, rather than propositional dissonance, to motivate alternative responses.

Vygotsky's testing paradigms and those of current researchers reflect children's shift from sensory-motor (perceptual/propositional) intelligence to logical intelligence; the experimental designs recognize that underlying the ontogenetic shift is a semiotic advance to exploit indexical meanings/effects, because such signs inherently serve as social/cultural tools. According to Vygotsky (1997[1930]: 96), such tools/artifacts are dialogic in nature and serve as primary facilitators to hasten mental regulation/reflective skills:

The mother draws the child's attention to something. The child follows the instructions and pays attention to what she points out. Here we always have two separate functions. Then the child begins to direct his attention himself, plays the role of the mother vis-à-vis himself. He develops a complex system of functions that were originally shared. One person orders, the other carries out. Man orders and obeys himself. (Vygotsky 1997[1930]: 96)

Here Vygotsky illustrates the impact of dialogic exchanges (cf. Wertsch 1980), and how their character alters to enhance reflective and self-regulatory skills. He claims that children initially depend upon social tools (another's instruction); then they depend upon internalized representations to enhance problem-solving (cf. Werani 2014; West 2019c). With respect to the latter process (in which dialogic processes are internal), Van der Veer (2007: 45) notes Vygotsky's characterization to be "doubled experience" or "doubling experience". Van der Veer likens Vygotsky's doubled experience to "a preestablished plan" whereby "the finished product first existed as a mental image or intention in the mind" (Van der Veer 2007: 45). Yet for Vygotsky, unlike Peirce, the mental image only comprises one half of the experience, the other half is attention and action-based in nature: "Such doubled experience allows man to develop active forms of adaptation which the animal does not have. Let us provisionally call this new type of behavior doubled experience. Now the new part of the formula of human behavior looks like this: historical experience, social experience, and doubled experience" (Vygotsky 1987[1925]: 68-69). Conversely, Peirce considers both halves of the experience to be cognitive (CP 8.330) and therefore double consciousness instead of doubled experience.

The sign which most efficaciously brings children's attention to doubled experience is the index. Index materializes early on in the form of pointing to establish and maintain self focus (Bates 1976: 61), object showing (Liszkowski, Tomasello 
2011), and proceeding to the appreciation of objectified dialogic perspectives (for further discussion cf. West 2013, 2016). In support of this Vygotskian approach, Sannino (2015: 9) supports the claim that advances in indexical use are responsible for increased appreciation of the power of dialogue to inform inferencing: "the pointing finger is the key component in mastering [...] voluntary [mediated] attention". This is the case early on in development when attention is restricted to distinct perceptual components. At this juncture, pointing, as well as other indexical signs are used solely to individuate and to make salient iconic features intrinsic to physical objects. Later, when indexical signs take into consideration the meanings that others assign, they can highlight Vygotsky's critical competency of conflicts of motive. In this way, the logical and dialogic skills necessary for double stimulation exercises can reliably be performed. Magnani's (2017) ecocognitive model takes note of this inextricable semiotic advance (especially present early in development) made efficacious by the combinatory use of perceptual artifacts, e.g., indexical pointing, and linguistic artifacts (especially indexical legisigns). Magnani intimates that together they enhance long- and short-term memory processing and storage. Hence, Vygotsky's model together with that of Magnani, is semio-cultural in nature; they assume that representational competencies (rather than bear sensorimotor psychological ones) underlie the shift from natural tools to cultural ones, and intimate the higher-order place for purposeful action in inference-making.

\section{Elementary double stimulation paradigms}

Several experimental designs have attempted to measure younger children's (their ages ranging from $2 ; 0$ to $4 ; 0$ ) double stimulation skills, and to offer interventions to heighten such skills. The testing paradigms require subjects to respond in one of two ways in two different semiotically altered contexts. These alterations include binary situations in which children, even at 3;0, are forced to exercise greater levels of conscious attention, in one context, while employing automatic attention in the other context/phase.

Reed, Pien, and Rothbart (1984) measured double stimulation competencies at 3;0 to 5;0 on the Bear and Dragon Test. Subjects were introduced to a "nice" bear puppet and a "naughty" dragon puppet. While the bear puppet's voice was high-pitched (sweet), the dragon puppet's voice was deep/rough. Children were instructed "to obey the bear only (because it is 'nice', but not to obey the dragon (because it is 'naughty')". The investigators' intent was to construct a conflictual situation paradigm similar to that of "Simon Says", but requiring fewer cognitive 
competencies (Reed, Pien, Rothbart 1984: 160; cf. Strommen 1973). The most gains in performance were noted in subjects approaching the four-year-mark performance was far more successful after 3;7 (51\% prior to 3;7, and 76\% thereafter). Not until the five-year-mark did subjects' scores approach $95 \%$ (Reed, Pien, Rothbart. 1984: 168). Successful performance on the dragon trials (ignoring the dragon's commands but not those of the bear) was interpreted to indicate selfcontrol (Reed, Pien, Rothbart 1984: 607) - which appeared not to materialize until nearly $4 ; 0$. The self-control in deliberately not obeying the dragon's commands (exercised at 4;0) demonstrates that a new feeling (in Peirce's terminology) has "destroyed the old feeling" (CP 5.181). The new feeling is equivocal to obeying only "nice" "people"; children abandoned the old feeling (conviction) to obey any "person" without question. Reed, Pien and Rothbart's findings indicate that by 4;0 children do not merely discern a conflict between old and new facts (the bear behaves with kindness, while the dragon's intent is "naughty"); they likewise have had to weigh which response on their part would keep the "naughty" instructor at bay (perhaps extinguishing the dragon's involvement) - an unequivocally conscious skill. Further indication that consciousness is operational (particularly in its double form) is the change in habit of belief/conduct on the part of the subjects - in ignoring the undesirable model. The change in behaviour illustrates that conscious thought brought them beyond the struggle of whom to obey. At this juncture in development, double conscious practices of considering two feelings of belief and action result in a resolution - a change in their own habit toward the puppets.

Although instructions for the Bear and Dragon test are less complex than those of the standard "Simon Says" game, following instructions is still more difficult than instructions provided in a paradigm where attentional control is dependent upon abstract knowledge. In the Weighted Cube experiment (to follow), obeying commands was not required; and simple compliance with instructions/commands (as in the Bear and Dragon Test) requires far less consciously-based attentional skills - responses are rather automatic (especially given adherence to social preferences). Physical location determinations as in the following Weighted Cube Test, demand more spontaneous self-control over which events are relevant to which consequences - a competency primary to abductive rationality.

Veraksa (1987) required subjects of similar ages $(4 ; 0$ and 5;0) to determine whether a Weighted Cube would fall from a table surface; they were never made aware of the mechanism responsible for the cube's balance. A cube was placed on a table; most of it was extending beyond the table's edge, while the experimenter held it for balance. Subjects were then asked whether the cube would fall were the experimenter to release it. An affirmative response would prompt 
the experimenter to reposition the weight within the cube to cause it to remain upright, without falling. A negative answer would prompt the experimenter to reposition the weight, so that the cube would in fact fall. These repositionings continued until the subject requested termination. Findings revealed that fourand five-year olds would often hesitate before providing responses, clearly indicating their appreciation of two opposing viewpoints pertaining to the same object's functionality (Veraksa 1987: 31). This appreciation necessarily rests upon some degree of consciousness, to hold in working memory the two contrasting elements, and eventually (at older ages) to resolve the conflict after additional attempts of double consciousness consideration. For this more abstract skill, subjects (even at $4 ; 0$ and $5 ; 0$ ) did not demonstrate the competency to provide explanations for why the cube did or did not fall; consequently, the means to abduce appeared not to be operational, perhaps because of the abstract (non-social) nature of the task. Veraksa appears to support the present interpretation - that logical, explanatory competencies are not apparent at this age. In Veraksa's (2018: 33) analysis of his 1987 findings, subjects clearly demonstrated the means to engage in diverse dialogical perspectives, given their ability to engage in dialectical transformations, mediations, and reversals. He nonetheless points out that subjects' opposing contrasts appear to have been driven by imaginary, perhaps magical processes, rather than upon logically-based inferential reasoning.

\section{Intermediate double stimulation paradigms}

The primary distinguishing factor of intermediate designs is introduction of an auxiliary stimulus for memory enhancement. Vygotsky demonstrates that this kind of stimulus can be effective beyond the five-year mark (but especially after $8 ; 0)$ given children's increased means to exploit diverse and abstract meanings. In this vein, Vygotsky and Leont'ev extended a simple colour association design to incorporate a secondary stimulus. The purpose of this secondary stimulus was to facilitate double stimulation further - to have children recognize (and not ignore) perceptual/logical conflicts. It entails children's use of an external stimulus as a physical tool, to preclude automatic/verbatim responses, e.g., not to respond with the typical colour of a presented stimulus ('green' for 'grass,') but to articulate a different colour. An external stimulus (e.g., displacing a card displaying the already articulated colour) was expected to hasten children's attentional mediation at increasingly more advanced ages.

Vygotsky (1997[1931]): 155) found that at more intermediate ages (representing his second level of double stimulation competencies) subjects utilized the 
auxiliary stimulus only slightly over half of the time - to remember better that on the second pass for that object they were to articulate a different colour. Subjects at 6;0 did not always utilize coloured card displacement as a memory aid; only those children beyond $8 ; 0$ reliably depended upon these devices to remember better that they were expected not to proceed automatically, but in accordance with instructions: "Sometimes the child solves the problem completely differently. He does not put the forbidden colors aside, but selects them and puts them before him and fixes his eyes on them. In these cases, the external device corresponds precisely to the internal operation, and we have before us the operation of mediated attention" (Vygotsky 1997[1931]: 157). Interestingly, some of Vygotsky's subjects employed a different strategy for the use of the cards - rather than putting them aside, they scrutinized them more closely. In any case, the subjects still exploited the auxiliary stimulus for memory enhancement. Decision-making at this stage is mediated by the extent to which subjects are able to balance their negative affect in whether to perform automatically, or to obey the instructions. Subjects must determine which outcome is more advantageous. Much internal conflict surfaces at these intermediate ages (between 4;0 and 7;0), such that double conscious mechanisms are in effect to moderate the clash of new and old associations. Accordingly, ego-based outcomes and other-based outcomes often clash. Several more recent experimental paradigms have been developed to measure the conflict of motive competencies which Vygotsky originally identified.

Veraksa (2014) developed "The Odd One Out" paradigm whose purpose was to force children (at 5;0) to apply more objective (less automatic/verbatim) rationale - so that advantages for the self would become less relevant/available to select incongruent contextual stimuli. Children were shown sets of four pictures of familiar objects, and were expected to choose the one which did not belong, "the odd one out" (Veraksa 2014: 120). Then, they were expected to supply a term which defined the commonality (using an essential attribute) of those which did belong, together with rationale for the choice. No differences in performance were observed across the age groups (5;0 and 6;0) - both articulated essential attributes equally frequently. But their explanations for attribute selections were logically inadequate; they were based upon physical characteristics (shape) only (characterized as their "non-essential attributes"), rather than on functional ones. For example, they focused on the round shape of an apple rather than on its similarity to other fruit (Veraksa 2014: 121). The conflict which Veraksa examined is that between perceptual and functional attributes; but because of his heavy reliance upon linguistic competency to interpret the instructions, his findings underdetermined the degree to which subjects could mediate the conflict. Dependence often underdetermines underlying logic of anomalies/conflicts that children may well 
have internalized. Rather than requesting explanations to specify the commonalities across the stimuli comparable, Veraksa might have had subjects select pictures which depict the common function. An additional enhancement, such as having subjects interact with the "odd one out" stimulus, would illustrate its conflictual function through an enactment. This design alteration has the advantage of forcing subjects to reflect upon the conflict, which, in turn, is likely to heighten their awareness of underlying propositions to prepare for inference-making.

An additional paradigm which Veraksa (2014) developed to measure conflict of motive more adequately is the "Cycles Test". This approach is modelled upon one of Piaget's dialectic situation paradigms, which likewise illustrates attempts to make more precise the emergence of dialectical structures (Veraksa 2014: 119). Veraksa (2014: 120) targeted recognition and resolution of logical incongruities within five-year-olds' performance on reorganizing inaccurate states of affair progressive sequences. The test involved 14 items each consisting of two task cards with pictures of various natural phenomena (i.e. thunderstorms, change of seasons) and other physical phenomena (i.e. dissolution of a sugar cube in water), and everyday activities (i.e. sleep, personal hygiene). Cards depicting event sequences were arranged in two-by-three row configurations: the upper "task row" consisting of a depiction of a series of three frames - the two end frames filled, with the middle frame empty. The latter is the frame which children were expected to fill with a card from the three cards within the lower three-by-two array (lower "options row"). The first filled picture of the task (upper left) was intended to represent the initial state of the phenomena; and the last filled frame (on the upper right) depicted the final state. For example, one trial depicted the change in state of sugar cubes melting within a glass of warm water, such that the left-most glass showed nothing inside. The logical construct which experimenters attempted to measure was knowledge of the progressive states involved in the sugar cubes' dissolution, together with their explanation of the process. The second phase represented a reversal of the three frames - illustrating a reversal of the melting process, for which performance was understandably low, given the unnatural, inverse sequence of undoing. In fact, many children persisted with their answers from the first condition. Instead of choosing an appropriate picture from the options row, they simply defended their previous choice claiming that the test row pictures were just "incorrect" or "mixed up" (Veraksa 2014: 120). These inadequate explanations demonstrate subjects' lack of will to confront conflicts of motive, manifesting their propensity to put aside/ignore disparate states of affairs. In short, subjects' low performance on both paradigms ("The Odd One Out" and "Cycles Test") supports Veraksa's primary claim that, because generalization is a tool of formal logic, it is not ordinarily operational until beyond 
5;0. Subjects' reversals and faulty explanations demonstrate difficulties utilizing reciprocal/dialogic logic to enhance dialectic cognition (Veraksa 2014: 120, cf. Veraksa, Veresov 2018). In other words, at 5;0, children lack the back-and-forth, reciprocal cognitive skill which facilitates plausible reasoning and which informs more pluralistic logic.

\section{Advanced double stimulation paradigms}

Vygotsky's third and fourth stages of double stimulation skills become operational at approximately 8;0. These levels of double stimulation demonstrate further attentional control over the use of auxiliary stimuli as a consequence of internalization. The process comes to rely upon self-control to decide between courses of action - superseding the interventive effect of physical or linguistic stimuli. The self-control element in this more advanced paradigm incorporates more than stark attentional factors; because of children's increased means to appreciate objective avenues of mind, e.g., cultural and well-reasoned preferential ones, selfcontrol extends to affective and moral issues. To uncover how this more extended level of self-control promotes recognition of and appreciation for others' plights, Vygotsky constructed an experimental paradigm which would measure when children would abandon their own satisfaction and make a decision whose effects are more favourable to another's welfare, or presentment of a scenario whose diverse outcomes upon the self would have similar consequences. This kind of situation forces children to reason - arrive at a decision by means of foresight, distinguishing the conflicting possibilities of specific consequences.

Vygotsky refers to this state of consciousness as "conflict of motives". Conflict of motives entails a logical (mental) structure which privileges argument construction by comparing the effects of distinctive consequences. In this way, logical representations (arguments), rather than physical stimuli, drive children to use a different kind of auxiliary stimulus (less iconic) when selecting a course of action. Accordingly, they must balance logical principles and outcomes against individual inclinations to arrive at a "better" course of action.

The qualitative changes were evident in that the unequivocal motive was replaced by ambiguous motives and this resulted in a complex adjustment with respect to the given series of actions. [...] From the aspect of method, the substantial change [equivocal rather than ambiguous motives] introduced by this device [increasing possible alternatives for decision-making] consists in our being able to create motive experimentally since the series which we use are flexible and can be increased, decreased, replaced in part, and finally moved from series to series. (Vygotsky 1997[1931]: 207-208) 
In this experimental design, Vygotsky manipulates the number of conflicts to resolve (increasing them) to force an ultimate decision for self or for the general other. This design demonstrates that older children still utilize and command the use of physical devices to enhance attention, memory, and conflict resolution, but they now often likewise depend upon more objective, mental artifacts to organize decisions: "Older school children use external devices most fully and most adequately; they no longer exhibit complete dependence on the cards [external stimuli] as do the younger children" (Vygotsky 1997[1931]: 156). Instead of utilizing physical devices (coloured cards and their displacement) to determine the nature of their decision, children selected mental instruments, namely, actionimages depicting the logical flow from antecedent to consequent.

Rather than employing a physical stimulus as a memory/meaning aid, older children rely upon a mental "auxiliary stimulus", a neutral but internal device which helps organize/regulate decisions regarding outcome-change (Sannino 2015: 9-10; Vygotsky 1997[1931]: 210). Vygotsky's unique watch design experiment, in which children wait in an empty room without a purpose until they make the decision to leave, challenges children to "[...] recognize the need to make a choice based on motive and [...] his [the child's] freedom is the recognition of necessity. The child controls his selection reaction, but not in such a way as to change the laws that govern it," (Vygotsky 1997[1931]: 210). Younger subjects fail to modify more conventional "rules" because they have not yet reached the internal objectivity necessary to impose logical regulation to the best course of action in view of the potential consequences. Once children reach the degree of self-control (ordinarily at $8 ; 0$ ) in the conflict of motive experimental paradigms, abductive skills appear to be operational, because they possess the means to hold in the mind several potential outcomes without involving self as a participant (cf. West 2013: 67-92).

The kinds of auxiliary stimuli are more arbitrarily associated with the tenets of the decision; consequently, the decision requires representational competencies beyond similarity-based signification. Vygotsky's intent in introducing the neutral indexical stimulus (a watch) is to have subjects associate a sign (the stimulus) with an event, such that one stands for the other, and the subject is forced to arrive at a decision at that moment of whether to act. Vygotsky's purpose was to hasten children's "free choice" or self-control. These stimuli entail use of internal devices, rather than external ones as a catalyst to force a decision. For example, a watch is employed in an empty room (absent any physical or social stimuli) to direct children's notice of time passing, and the need to decide whether to stay in the face of "no purpose," or to leave (Vygotsky 1997[1931]: 212). Vygotsky introduces auxiliary stimuli to avoid a failure to act/decide, intensifying the conflict of motive. 
The urgency to act/decide is perpetuated by the emergence of affective conflicts to obviate logical ones.

Children look to the auxiliary stimulus (a die or a watch) to determine which objects to attend to, and which ultimate course of action should be implemented (Vygotsky 1997[1931]: 210): "He [the child] decides in advance that if the die turns black side up, he will choose one series and if it turns white side up, the other series. In this way, the choice is made in advance" (Vygotsky 1997[1931]: 212). In these paradigms, the auxiliary stimulus serves as the "motive" to exercise decision-making, in that it becomes an "actuating mechanism", replacing children's will, to compel a decision. This apparatus prevents the interference of children's consciousness. In brief, reliance upon an internal auxiliary stimulus guards against not-acting, and ensures that a selection is made. It does so through two processes of "voluntary acts": associating (via neuro-connections) the new stimulus to the decision situation, then creating a "motive" to act by aligning their [children's] responses to alterations within that stimulus (Vygotsky 1997[1931]: 214). Here, Vygotsky underscores the "voluntary" nature of choosing new over old (already stored) propositions. The voluntary factor is a real advance; it demonstrates that what underlies decisions is consciousness, not mere verbatim/automatic compliance with self's preexisting approaches, or those issued by others. Vygotsky's paradigm and its rationale, however, lack the more advanced logical competency of extending one's internal habits to the belief and action habits of another by sharing diverse argumentative structures.

This operation of searching for alternative perspectives (especially from reliable others) forces children to operate still more consciously in the context of event relations - facilitating higher-level inferencing skills. Vygotsky (1994[1931]: 208) describes this phenomenon as follows: "a particular method of experimental investigation $[\ldots]$ using two groups of stimuli $[\ldots]$. One group [...] has the function of a task toward which the activity of the experimental subject is directed, whilst the other takes on the function of signs which help to organize the activity". Although this method is useful for adults, it is especially efficacious to measure children's semiotic progress, in that it can determine the precise onset of truly representational thought. Vygotsky's attempts to disentangle attentional stimuli/control from control over the meanings/effects of internal images is an informative approach. It can reveal children's underlying readiness to spontaneously augment sign meanings, demonstrating semiosis at embryonic stages. Vygotsky further shows that when stimuli are utilized as "secondary/auxiliary" (Vygotsky, Luria 1994[1930]), they later govern "object/first stimuli" (Sakharov 1994[1930]), and enhance problem-solving rationale. Nonetheless, Vygotsky's failure to measure conflict of motive as interpsychological interchanges leaves us 
without a mechanism to measure the dialogic processes inherent in inferential reasoning.

Vygotsky's conflict of motive paradigms are still in need of elaboration because these conflicts are limited to propositional logic. Subjects were forced to integrate other simple predicates (e.g. colour, shape) rather than tracing how propositions become assertions within the same or another mind. His double stimulation method required subjects to disregard an automatic response and construct an alternative explanation for the less obvious condition. Vygotsky's double stimulation paradigms forced subjects to contemplate conflict situations, but unfortunately without incorporating the natural emergence of a surprising event. Vygotsky and his colleagues did not recognize surprise as the noticing catalyst for apprehending anomalies for settling upon different, more objective courses of action/belief. Absent some element of surprise, children might not attend to meaningful factors of the conflict.

\section{The element of surprise}

Peirce's model proposes that the element of surprise inherent within dialogic forums provides the motivation and practice necessary for sound inferencing. First, surprise animates interpreters to notice logical conflicts - for mastery of reliable techniques to ascertain the most plausible arguments. In fact, the effect of surprise is most potent when Peirce features it within the forum of double consciousness. This is so, given the pivotal role of surprise in sharing perceived truths within each proposition of the conflicts underlying cause-effect events. Ultimately, the surprise component of dialogic exchanges provides the attentional mechanism without which more advanced inferential processes, such as recommending courses of action ${ }^{4}$ (likewise reliant upon dialogic interaction), would be unlikely to surface. The contribution of surprise to resolve conflicts within regimes of double consciousness marks the onset of habit-change, demonstrating how unexpected happenings promote intrapsychological and interpsychological dialogue. It is just this dialogic interchange which ultimately hastens the most productive kind of reasoning where viable insights and plausible constructive abductions are particularly informative.

Peirce advocates that a two-sided conflict of thought constitutes a necessary and primary component in facilitating novel insights. The dialogic interactions obviating belief/action conflicts begin with attention to the viability attributed to

4 "It will be remarked that the result of both Practical and Scientific Retroduction is to recommend a course of action" (MS637: 12). 
a different proposition (derived from a vivid, surprising circumstance). A flash of insight surfaces as a consequence of the affirmative impact of an unexpected event - suggesting that preexisting propositions/arguments are in need of change. According to Peirce, this insight emanates from outside forces such as vividness (cf. Atkins 2018: 195; MS318, 1907; MS643, 1909). The primary advantage of vividness in surprise within double consciousness is its attentional benefit for determining whether the old or the new knowledge better cultivates truth principles. As such, focus is secured to vivid consequences, calling for explications of their logical relationship with antecedents. To determine the value of the insight flowing from the vivid, surprising circumstance, subjects rely upon a two-sided consciousness (CP 5.53), whereby either the insight is discarded as a hypothesis, or new propositions/arguments are presented (CP 8.373). The purpose of the two-sided argumentative venue is to reconstitute propositions in such a way that certain subjects are chunked with certain predicates to be best processed within the confines of the working memory system. The intrusion of novel propositions/ assertions within working memory are accorded greater power to compete with old propositions when their meanings or effects are well differentiated with the potential of eliciting conduct or belief alterations. These forms of dialogue influence the inferencing process: an agent's propositions/arguments compel a receiver's acceptance/rejection, which determines whether the propositions/arguments will ultimately be included within the respective inference. Both models (Peirce's double consciousness and Vygotsky's double stimulation) reveal the necessity for dialogic exchange within or between minds to initiate and maintain the process of inferential rationality. These double, interactive forums draw in the mind intrusions into established assertions; they constitute novel propositional suggestions in the form of subject-predicate diagrammatical paradigms. In short, in view of its extraordinary means to secure the attention to vivid features in the external world, the element of surprise supplies the affective fervour for truth value consideration later, within dialogic forums. Surprise accounts for how the abducer arrives at more sound inferences - the emergence of sudden explanatory insights for novel states of affairs:

Examine the percept in the particularly marked case in which it comes as a surprise. At the moment when it was expected the vividness of the representation is exalted. [...] Something quite different comes instead. I ask you whether at that instant of surprise that there is not a double consciousness, on the one hand of an ego, which is simply the expected idea suddenly broken off, on the other hand of a non-ego, which is the strange intruder, in his abrupt entrance. (CP 5.53) 
The non-ego as a "strange intruder in his abrupt entrance" obviates the process created by the destruction of one feeling by another (CP 8.330). In fact, but for the emergence of a new feeling (sense of gathering attention to something legitimate) and comparison with the former feeling, the effect of the Dynamical Object would have little influence in resolving the double consciousness conflict. Accordingly, it is just the comparison between the feelings which underlies notice that the Dynamical Object is somehow distinct from the Immediate Object - from previous conceptions accorded to the object. In short, notice of the unique properties to be newly ascribed to the Immediate Object would be an unlikely prospect, absent a war between feelings. According to Peirce (MS 298, 1906) and Atkins (2018: 195-196), vividness is a feature of Secondness which initiates surprise in the notice of differentness and salience. Peirce makes the influence of vividness crystal clear: it "riles the limpidity of our thoughts and interferes with our business" (MS 298). As such, salience to the novelty that it might bring is heightened primarily by two factors: the personal nature of the source, and the insistence of the external object in Secondness with its context. With respect to the former, the signer's own storage of facts in long-term memory and his consideration of new information in working memory suggest a new way forward - of action or belief (cf. Baddeley 2007; Baddeley, Andrade 2000). These voices mediate abductive rationality, in that a directive for habit change proceeds from the beholder's own memory system. In other words, the element of surprise in the vividness of the internal picture enhances the potency for determining the validity of the implied proposition. However, the conflict resulting from the surprise upon notice of a new proposition within a creative hallucination ${ }^{5}$ (cf. EP2: 192; Gregory 2016; Alderson-Day, et al. 2014, West 2020) necessarily requires a comparison of "feelings," for Peirce:

[...] nor could I call my Quality a Feeling, since the simplest feeling is more complex. My quality is an element of feeling. Every feeling has a greater or less degree of vividness; but vividness results from a comparison of feelings. It is the contrast between one's general state of feeling before a given sensation and during that sensation. This [is] the sense of commotion. Now every feeling appears to be accompanied by this sense of commotion which is reckoned a part of it. [...] Besides, there is a much greater objection to calling my Quality of feeling. Namely, by a Feeling we mean something that arises in a mind. It is essentially something

5 Peirce refers to these phenomena (equivocal to abductions) as "hallucinatory imaginations" in the context of a visit to an artist's studio, finding himself "utterly destitute of any such hallucinatory imagination": "Of course, the man knows that such obedient spectres are not real experiences, because experience is that which forces itself upon him, will-he nill-he. Hallucinations proper, - obsessional hallucinations, - will not down at one's bidding..." (EP2: 192). 
which exists only as a state of something else, namely, a mind. But, my Quality is whatever it is of itself. And it would occasion frightful misconception to call it a Feeling. (PPM 141)

Peirce is clear that feelings are not qualities; their functions supersede those of quality. ${ }^{6}$ They appear to rise to the level of proto assertions, since they rise to the level of specific determinations; and some degree of motivation, as in decisionbased conviction accompanies them. Furthermore, feelings almost always entail a comparison/conflict - to align with one feeling, while rejecting/shelving others. The new feeling (which manifests "quality") is either assimilated into previous feelings (old feelings), or is opposed to them. Although this feeling constitutes Firstness, the conflict between feelings in causing commotion demonstrates that Secondness holds a more prominent effect, given the dualistic struggle intrinsic to the two-sided old versus new motivation to notice and incorporate the new premises into conclusions (cf. MS 514: 16).

Nevertheless, it must not be overlooked that it is surprise that promotes the sudden commotion among feelings, necessary to promote dialogic thought and abductive rationality. Still, absent the truth-seeking process inherent in hypothesis formation and evaluation, the success of dialogic thought would be truncated. The further need for the Dynamical Object to intrude upon an interpreter's Immediate Object is critical to ultimately operate abductively, because it draws attention to some heretofore unrealized characteristic of the object, making salient some hitherto unconsidered form of the meaning. Peirce considers this intrusion to be of supreme importance; the new insight must "rile the limpidity of our thoughts, [...] interfering with our business" (MS 298); otherwise, we might well shelve it, and fail to exploit its affective, cultural, and logical advantages. Because surprise draws attention to the viability of the new fact, it is necessarily indexical (cf. West 2019d); and it is the directive capacity of interlocutors (one showing new arguments to another's notice) within double consciousness regimes which regulates the clash (that Peirce identifies) between feelings. This, coupled with the imposition of the Dynamical Object upon the interpreters' consciousness accounts for index's influence in dialogic rationality. The sudden intrusion of the Dynamical Object upon

$6 \quad$ To distinguish between feelings and qualities further, cf. MS 645: 9: "For Feeling is a Quality and though it certainly has two Quantities connected with it, its total intensity and the relative intensity of its leading ingredient, both being Quantities of Quality, I do not recognize Vividness as the Quantity of any Quality or predicate at all, but simply as a non-relative or non-predicative Quantity. Now, what is non-predicative Quantity that is a Prebit? It is a force. On the other hand, Quality is entirely passive, and is no force. Vividness, therefore, is no part or essential attribute of a Feeling: it is something of an utterly different nature." 
the Immediate Object likewise produces the incongruity (clash) between feelings. It is evident that double consciousness comes to fruition with the imposition of surprise, together with the sources which produce the clash between feelings. In short, without the attentional devices intrinsic to the feeling shifts within double consciousness, plausible hypotheses would be either discarded or ignored, for they would be stripped of a contemplative complexion.

\section{Double consciousness in the inferencing process}

Although Peirce does not explicitly characterize the process of double consciousness (internal or external dialogue) in ontogeny, he does articulate its effect upon reasoning, intimating reliance upon interactive cognition from early ages. Double consciousness supplies a practical give-and-take deliberate interchange to convert mere percepts/happenings into experiences (CP 8.330). By applying interpretive measures, percepts become percipua and "perceptual judgments": "[...] I propose to consider the percept as it is immediately interpreted in the perceptual judgement, under the name of the 'percipuum'[...]" (CP 7.643). Here Peirce distinguishes the percept from the percipuum and the perceptual judgment in that it stands as the beginning of the application of interpretation to the percept - setting the stage for perceptual judgments.

Turning verbatim happenings or percepts into experiences requires a war between feelings - "the action of a new feeling in destroying the old feeling is what I call an experience" (CP 8.330). Essentially, an experience consists in the application of interpretive processes by way of a two-sided perspectival opposition, in which feelings/meanings of signs conflict; and resolution of these conflicts is required (CP 8.330). In short, Peirce uses "experience" as a synonym for a novel interpretation, whether subjective or objective. Still, it is only when inferences are constructed upon more objective explanations that experience is a factor in their constitution.

The double-sided meaning interchange inherent in the double-consciousness process exists between ego and non-ego (CP 5.53) or information mediation between quasi-minds ( CP 4.551), corresponding to exchanges of old versus new assertions, respectively. Peirce attests to the inherently dialogic nature of this double exchange: "[...] it is not a fact of human psychology, but a necessity of logic, that every logical evolution of thought should be dialogic" (CP 4.551). Because this process is unquestionably dialogic (psychologically and logically) in that it requires two quasi-minds relying upon at least some common knowledge and constructing future meanings (1906: CP 4.551; Pietarinen 2006), it permeates 
all sign use. This meaning-sharing emanates from all of Peirce's categories: in Firstness (in conflictual feelings), in Secondness (where oppositions are individuated in actual happenings), or in Thirdness (where conceived mediational processes operate). A certain kernel needs to be common to two quasi-minds to make meaning. Mediational processes operate when the interpreters, although "distinct" as communicative partners, are "welded in the sign" as "one mind" (CP 4.551). In view of the breadth of dependence upon dialogic, shared meanings between the quasi-utterer and the quasi-interpreter (CP 4.551), sign use is implicated in presenting, and recommending alternative interpretations. In fact, it is the dialogical nature of double consciousness that obviates the logical effects of antecedents upon potential consequences. In short, Peirce's dialogic model for enhancing abductive reasoning assumes that sign use is foundational to the ontogenetic and interventional advances inherent in generating sound inferences. In other words, double consciousness furnishes the most fertile forum to promote sound inferential reasoning, given its reliance upon alterity to confirm shared meanings, and to uncover novel assertions. Dependence upon sharing meanings between interacting parties (a quasi-utterer and a quasi-interpreter) is paramount to exploring how meanings are aligned, and whether the interpreting party to the exchange determines that an alteration in meaning is recommended either by the interpreter him/herself, or by the utterer's implied/explicit suggestions. Because inferencemaking emanates from conflicts destined for resolve by way of proposed alternative assertions, it necessarily relies upon the dialogic up-take of meaning proposals. Quasi-interpreters then enter a determination phase - whether a change to old assertions is advisable; hence double consciousness effectuates the issuance of imperatives, interrogatives, and declarative moods in the process of determining objective truth.

Imperative based influences operate when dual perspectives establish a mental give-and-take forum in which meaning conflicts become obviated via the element of surprise. Unexpected meanings ascribed to subject-predicate associations force interpreters to attend to and contemplate new propositions/arguments. The unique nature of double consciousness in its means to command results in a range of influence - from bear nudges for belief change, to moderate recommendations, or to vital compliance. The forums through which these meanings are presented in double consciousness can surface either within self-talk interactions, in which notice of new meanings derives from the beholder's own internal, interpretive competencies, or in others' assertions, be they pictures, gestural performatives (West 2019b), or linguistic performatives. Pictures communicate commands, interrogations, or suggestions for future beliefs/conduct. They constitute an exchange of meanings; and although the exchange is not obvious given the 
unobservability of the interpretant (when not explicit), the exchange is, nonetheless, a fledgling illustration of how emerging meanings illustrate the sign's potency to house logical truths even before they are transferred to another mind (cf. discussion of Thirdness in its pregenerative form in Deely 2015 and West 2019a). As such, future meanings are "provenated" in the implicit propositions of emergent pictures in ego's own mind, or in the action performatives produced by another to command conduct/different beliefs, or in the explicit linguistic performatives which "say" new imperative propositions. The latter surfaces when articulated in speech (external, internal) dialogue where syntax further regulates the suggestion of novel propositions.

The internal form of double consciousness entails attention to and reconsideration of distinctive meanings of percepts - beyond verbatim ones. Hence, the process requires application of interpretive skills found in Peirce's "percipua", or in his "perceptual judgments" (CP 7.643; Short 2007: 319). This exchange demonstrates an imperative/interrogative operation in which internal semiotic conflict is forged:

But it is in conflict with the facts which are that a man is more or less placidly expecting one result, and suddenly finds something in contrast to that forcing itself upon his recognition. A duality is thus forced upon him: on the one hand, his expectation which he had been attributing to Nature, but which he is now compelled to attribute to some more inner world, and on the other hand, a strong new phenomenon which shoves that expectation into the background and occupies its place. The old expectation, which is what he was familiar with, is his inner world, or ego. The new phenomenon, the stranger, is from the exterior world or non-ego. (EP2: 195)

The duality which Peirce describes between the expectation and the new phenomenon (the latter he calls "irresistible [...] imperative" in CP 5.181) is but another illustration of the struggle of the new feeling (novel proposition/argument) in obliterating the old feeling (consonant with Peirce's characterization of destruction of feelings in CP 8.330). The external element (the outer world fact) replaces pre-existing assertions; and the emerging expectation of what the feeling will afford is tantamount to a conviction - seeds for assertions. This conviction is intrinsic to Peirce's very concept of feeling, highlighted by the intrusion of another feeling to destroy the former, hence initiating a change in habit. Secondness likewise emerges as a primary factor - providing feelings (novel notions extracted from outside ego) to inform interpretations such that they are not confined to a closed or non-updatable representational system. In forums of double consciousness, interpreters become aware of the mental and practical effects of the outside intruder, and experience havoc caused by its conflict with expectations in 
Firstness. Accordingly, the primary characterization of all instantiations of double consciousness is a struggle (in Secondness) to alight upon the most reasonable interpretation from the two-sided inquiry.

The primary indicator that a habit-change has been effectuated from double conscious struggles is whether a change in conduct/belief is activated. The struggle is described by Peirce as "commotion". Peirce defines "commotion" as the difference in sensation prior to and during that sensation (1903: PPM 141). This claim intimates that the force behind habit-change is always obviated in physiological terms. But in 1904, Peirce (CP 8.330) refers to this commotion as "an experience", whereby the two aspects of sensation coalesce into a new meaning which renovates beliefs or actions. In other words, commotion during the process of double consciousness need not be restricted to sensations (physiological responses); rather, interpreters orchestrate steps toward resolving the conflict by regulating consideration of opposing cognitions. Peirce determines this kind of commotion to be foundational to the inferencing process, which he refers to as "experience". To put it succinctly, the apprehension of a change in thought or action is an "experience". In short, an experience (awareness of the conflict via commotion) drives interpreters toward heightened awareness that a new way of handling states of affairs is necessary; hence they are driven to anticipate extracting useful (non-extraneous) information from alterity-based sources. When interpreters expect to take advantage of an internal insight or perspectives issued by another, they discriminately open themselves to receive them, anticipating their utility. Their increased anticipation of the value of particular sources of dialogue to react to demonstrates the affirmative effects of commotion - that it advances interim resolutions. The benefits of this anticipatory dialogue are immeasurable highlighting the impact of one's own declarations/suggestions/inquiries to self or to others, and sensitizing interpreters early on to the worth of others' assertions/ arguments. This anticipatory component assists in determining which hunches to filter out and which to garner.

\section{The growth of percepts in double-conscious regimes}

It is when these percipua/perceptual judgements are noticed - when they are vivid contributions to valid new perspectives - that abductions are born and habits are changed. Surprise constitutes the primary measure that a percipuum or a perceptual judgement will initiate a habit change. This habit change is directly consequent to the imposition of new information within the double consciousness forum upon the old; it is nothing less than a change in interpretation, but which is 
still subject to idiosyncratic and rather fallible reasoning. Unless interpreters surrender to the force of the Dynamical Object (in its irresistibility), they are unable to "yield to retroductions" - a critical effect of surrender in the first place (CP 5.181). Once interpreters yield to the truth of inferences, they embark upon a habit change. The new interpretation becomes a habit once the Dynamical Object has its influence: "cest plus fort que moi [it is stronger than I am]" (CP 5.181). At this juncture, the Immediate Object becomes modified to be in greater conformity with logical, objective principles. The Dynamical Object exists in the surprise of abduction; what Peirce calls stronger than himself is the hypothesis. The element of surprise surfaces consequent to attention to, or notice of, an unexpected Dynamical Object, and serves at the impetus for dialogic interchanges to discern its efficacy and to integrate it into hypotheses.

Peirce indicates in the same year that this "abrupt entrance" is occupied by a percept which becomes a perceptual judgement:

We know nothing about the percept otherwise than by testimony of the perceptual judgement, excepting that we feel the blow of it [percept] the reaction of it against us, and we see the contents of it arranged into an object, in its totality - excepting also, of course, what the psychologists are able to make out inferentially. But the moment we fix our minds upon it and think the least thing about the percept, it is the perceptual judgement that tells us what we so "perceive." For this and other reasons, I propose to consider the percept as it is immediately interpreted in the perceptual judgement, under the name of the "percipuum." The percipuum, then, is what forces itself upon your acknowledgement, without any why or wherefore, so that if anybody asks you why you should regard it as appearing so and so, all you can say, is "I can't help it. That is how I see it". (CP 7.643)

By a perceptual judgement, I mean a judgement asserting in propositional form what a character of a percept directly to the mind is. (CP 5.54)

It is evident that abductive rationality would not surface without the confluence of information communicated within double consciousness, because without it, the potential worth of different predicates assigned to different subjects would remain inactive - thwarting generation of plausible hypotheses. Hypotheses would either be discarded or would be ignored altogether before their efficacy could be determined. In short, it is the element of surprise hosted by double consciousness regimes (not simply Vygotsky's more contrived conflict of motive) that awakens one's attention to different states of affairs or to different perspectival orientations. It does so by tapping into the repertoire of Thirdness - by augmenting the signification of entities in Secondness, e.g., the percept's conversion into the "percipuum" (CP 7.643). 


\section{Conclusory remarks}

Although Vygotsky generated experiments to create conflict within children's preconceived assertions, he did not recognize the role of the unexpected in bringing before the mind unconsidered contributing factors. Instead, his purpose was to determine the inadequacy of previously held principles, perceptual, affective, or logical. Vygotsky's model took into consideration ascending levels of cognitive competencies at different ages. He monitored the cognitive complexity underlying conflict situations. As such, Vygotsky's crafting of experimental paradigms supplied practical information as to when propositions advance from a purely perceptual character to those advocating moral and logical objectives. Vygotsky's measurement paradigms, formidable because they demonstrate how children utilize conflictual information to make decisions and change behaviours, nonetheless overprivilege linguistic competencies.

Unlike Vygotsky, Peirce recognized the role of surprise in highlighting abductive processes. Peirce's concept of double consciousness allows for consideration of whether another mind would be open to particular novel claims or avenues in presenting those claims. Permitting children to experience surprising consequences through independent discovery and manipulation of events would enhance Vygotsky's experimental paradigm. In this way, processes of belief change and resultative action would be more adequately revealed. Viable hypotheses might emerge to inform not merely the practical affairs of single individuals, but objective logic at large.

\section{References}

Alderson-Day, Ben; McCarthy-Jones, Simon; Bedford, Sarah; Collins, Hannah; Dunne, Holly; Rooke, Chloe; Fernyhough, Charles 2014. Shot through with voices: Dissociation mediates the relationship between varieties of inner speech and auditory hallucination proneness. Consciousness and Cognition 27: 288-296. https://doi.org/10.1016/ j.concog.2014.05.010

Atkins, Richard Kenneth 2018. Charles S. Peirce's Phenomenology: Analysis and Consciousness. Oxford: Oxford University Press. https://doi.org/10.1093/oso/9780190887179. 001.0001

Baddeley, Alan 2007. Working Memory, Thought, and Action. Oxford: Oxford University Press. https://doi.org/10.1093/acprof:oso/9780198528012.001.0001

Baddeley, Alan; Andrade, Jackie 2000. Working memory and the vividness of imagery. Journal of Experimental Psychology General 129(1): 126-145. https://doi.org/10. 1037/0096-3445.129.1.126

Bates, Elizabeth 1976. Language and Context: The Acquisition of Pragmatics. New York: Academic Press. 
Bergman, Mats 2016. Beyond explication: Meaning and habit-change in Peirce's pragmatism. In: West, Donna; Anderson, Myrdene (eds.), Consensus on Peirce's Concept of Habit: Before and Beyond Consciousness. Heidelberg: Springer-Verlag, 171-197. https:// doi.org/10.1007/978-3-319-45920-2_11

Colapietro, Vincent 2015. C. S. Peirce's phenomenological categories: Their basic form, recursive elaboration, and heuristic purpose. Journal Phänomenologie 44: 10-20.

Cooke, Elizabeth F. 2012. Peirce on wonder, inquiry, and the ubiquity of surprise. Chinese Semiotic Studies 8: 178-200. https://doi.org/10.1515/css-2012-0037

Deely, John 2015. From semiosis to semioethics. In: Trifonas, Peter Pericles (ed.), The International Handbook of Semiotics. Heidelberg: Springer-Verlag, 771-789. https:// doi.org/10.1007/978-94-017-9404-6_36

Engeström, Yrjö 2007. Putting Vygotsky to work: The Change Laboratory as an application of double stimulation. In: Daniels, Harry; Cole, Michael;Wertsch, James V. (eds.), The Cambridge Companion to Vygotsky. Cambridge: Cambridge University Press, 363-382. https://doi.org/10.1017/CCOL0521831040.015

Fernyhough, Charles; Fradley, Emma 2005. Private speech on an executive task: Relations with task difficulty and task performance. Cognitive Development 20: 103-120. https:// doi.org/10.1016/j.cogdev.2004.11.002

Gregory, Daniel 2016. Inner speech, imagined speech, and auditory verbal hallucinations. Review of Philosophy and Psychology 7(3): 653-673. https://doi.org/10.1007/s13164015-0274-Z

Leont'ev, Aleksei Nikolaevich 1932. The development of voluntary attention in the child. Journal of Genetic Psychology 40: 52-81. https://doi.org/10.1080/08856559.1932.10534207

Liszkowski, Ulf; Michael Tomasello 2011. Individual differences in social, cognitive, and morphological aspects in infant pointing. Cognitive Development 26: 16-29. https://doi. org/10.1016/j.cogdev.2010.10.001

Magnani, Lorenzo 2017. The Abductive Structure of Scientific Creativity: An Essay on the Ecology of Cognition. Heidelberg: Springer-Verlag. https://doi.org/10.1007/978-3-31959256-5

Peirce, Charles S. 1931-1958[i. 1867-1913]. Collected Papers of Charles Sanders Peirce. [Hartshorne, Charles; Weiss, Paul, eds., vols. 1-6; Burks, Arthur W., ed., vols. 7-8.) Cambridge: Harvard University Press. [In-text references are to CP, followed by volume and paragraph numbers.]

Peirce, Charles S. 1992-1998[i. 1867-1913]. The Essential Peirce: Selected Philosophical Writings. Vol. 1 (Houser, Nathan; Kloesel, Christian, eds.,vol 1; Peirce Edition Project, eds., vol. 2). Bloomington: Indiana University Press. [In-text references are to EP, followed by volume and page numbers.]

Peirce, Charles S. 1997[1903]. Pragmatism as a Principle and Method of Right Thinking: The 1903 Harvard Lectures on Pragmatism. (Turrisi, Patricia, ed.) Albany: SUNY Press. [In-text references are to PPM.]

Peirce, Charles S. (i. 1867-1913). Unpublished manuscripts are dated according to the Annotated Catalogue of the Papers of Charles S. Peirce, ed. R. Robin (Amherst: University of Massachusetts Press, 1967), and confirmed by the Peirce Edition Project (Indiana University-Purdue University at Indianapolis). [In-text references are to MS, followed by manuscript number and, when available, page number.] 
Pietarinen, Ahti-Veikko 2006. Signs of Logic: Peircean Themes of the Philosophy of Language, Games, and Communication. Heidelberg: Springer-Verlag.

Reed, Marjorie; Pien, Diana; Rothbart, Mary 1984. Inhibitory self-control in preschool children. Merrill-Palmer Quarterly 30(2): 131-147.

Sakharov, Leonid 1994[1930]. Methods for investigating concepts. In: Van der Veer, René; Valsiner, Jaan (eds.), The Vygotsky Reader. Oxford: Blackwell, 73-98.

Sannino, Annalisa 2015. The principle of double stimulation: A path to volitional action. Learning, Culture, and Social Interaction 6: 1-15. https://doi.org/10.1016/j. lcsi.2015.01.001

Short, Thomas L. 2007. Peirce's Theory of Signs. Cambridge: Cambridge University Press. https://doi.org/10.1017/CBO9780511498350

Stjernfelt, Frederik 2014. Natural Propositions: The Actuality of Peirce's Doctrine of Dicisigns. Boston: Docent Press. https://doi.org/10.1007/s11229-014-0406-5

Strommen, Ellen A. 1973. Verbal self-regulation in a children's game: Impulsive errors on “Simon says". Child Development 44(4): 849-853. https://doi.org/10.2307/1127737

Van der Veer, René 2007. Lev Vygotsky. London: Continuum.

Veraksa, Nikolay 1987. Development of the suppositions of dialectical thinking at preschool age. Voprosy psikhologii 4: 135-139.

Veraksa, Nikolay 2014. Dialectic and formal structures in cognition of preschool children. Procedia- Social and Behavioral Sciences 146: 118-123. https://doi.org/10.1016/j. sbspro.2014.08.097

Veraksa, Nikolay; Veresov, Nikolai 2018. Dialectical thinking research in early years. In: Veraksa, Nikolay; Sheridan, Sonja (eds.), Vygotsky's Theory in Early Childhood Education and Research: Russian and Western Values. Oxford: Routledge, 25-37. https://doi.org/10.4324/9781315098203-3

Vygotsky, Lev S. 1994[1931]. Thinking and concept formation in adolescence. In: Van der Veer, René; Valsiner, Jaan (eds.), The Vygotsky Reader. Oxford: Blackwell, 185-265.

Vygotsky, Lev S. (1997[i. 1924-1930]). Problems of the Theory and History of Psychology (Collected Works of L. S. Vygotsky. Vol. 3). (Rieber, Robert; Wollock, Jeffrey, eds.) New York: Plenum Press.

Vygotsky, Lev S. (1997[1931]). The History of the Development of Higher Mental Functions (Collected Works of Vygotsky, Vol. 4). (Rieber, Robert, ed.). Heidelberg: Springer.

Vygotsky, Lev S.; Luria, Alexander 1994[1930]. Tool and symbol in child development. In: Van der Veer, René; Valsiner, Jaan (eds.), The Vygotsky Reader. Oxford: Blackwell, 99-174.

Werani, Anke 2014. A review of inner speech in cultural-historical tradition. In A. Yasnitsky, Anton; Van der Veer, René; Ferrari, Michel (eds.), The Cambridge Handbook of Cultural-Historical Psychology. Cambridge: Cambridge University Press, 272-294. https://doi.org/10.1017/CBO9781139028097.016

Wertsch, James V. 1980. The significance of dialogue in Vygotsky's account of social, egocentric, and inner speech. Contemporary Educational Psychology 5(2): 150-162. https:// doi.org/10.1016/0361-476X(80)90036-3

West, Donna 2013. Deictic Imaginings: Semiosis at Work and at Play. Heidelberg: SpringerVerlag. https://doi.org/10.1007/978-3-642-39443-0 
West, Donna 2016. Recommendations as imperative propositions in the operation of abductive reasoning: Peirce and beyond. IfCoLog Journal of Logics and their Applications 3(1): 123-150.

West, Donna 2017. Virtual habit as episode-builder in the inferencing process. Cognitive Semiotics 10(1): 55-75. https://doi.org/10.1515/cogsem-2017-0005

West, Donna 2019a. Semiotic determinants in episode-building: Beyond autonoetic consciousness. Filozofia i Nauka 7(1): 55-76. https://doi.org/10.37240/FiN.2019.7.2.1.4

West, Donna 2019b. From subjectivity to subjunctivity in children's performatives: Peirce's endoporeutic principle. Cognitive Semiotics 12(2). https://doi.org/10.1515/cogsem2019-2013

West, Donna 2019c. Narrative as diagram for problem-solving: Confluence between Peirce's and Vygotsky's semiotic. In: Owens, Geoffrey; Katić, Elvira (eds.), Semiotics 2018. Charlottesville: Philosophy Documentation Center Press 201-219. https://doi. org/10.5840/cpsem 201815

West, Donna 2019d. Index as scaffold to logical and final interpretants: Compulsive urges and modal submissions. Semiotica 228: 333-353. https://doi.org/10.1515/sem-20180085

West, Donna 2020. Auditory hallucinations as internal discourse: The intersection between Peirce's endoporeusis and double consciousness. In: Owens, Geoffrey; West Donna (eds.), Semiotics 2019. Charlottesville: Philosophy Documentation Center Press, 129-145. https://doi.org/10.5840/cpsem20195

Zavershneva, Elena 2014. The problem of consciousness in Vygotsky's cultural-historical psychology. In: Yasnitsky, Anton; Van der Veer, René; Ferrari, Michel (eds.), The Cambridge Handbook of Cultural-Historical Psychology. Cambridge: Cambridge University Press, 63-100. https://doi.org/10.1017/CBO9781139028097.005

\section{Диалогическая природа двойного сознания и двойного стимулирования: на основе теорий Пирса и Выготского}

Цель данной работы - продемонстрировать незаменимость понятия двойного сознания у Пирса для стимулирования абдуктивного мышления, где диалог (внешний/ внутренний) поддерживает ценность догадок. Эти формы диалога создают ментальную платформу для компромиссов, в которой новые значения/эффекты особенно выделяются и замечаются. Такие сдвиги внимания обусловлены примечательным положением дел в рамках внутренней, интерпретирующей компетенции субъекта или внешними факторами (рисунками, жестовыми или языковыми перформативами). Природа этих знаков невозможна без диалога: они «командуют», «допрашивают» или предлагают изменения в устоявшемся поведении/убеждениях в контекстах, в которых устраняются пропозиционные/аргументированные конфликты.

В работе предлагаются экспериментальные методики для измерения того, каким образом двойное сознание (с помощью внутренней речи) способствует порождению гипотез. Конфликт мотивов Выготского на четырех различных стадиях развития является основой для предлагаемых экспериментов. Проекты опираются на парадигмы «двойного стимулирования» Выготского, которые форсируют процессы 
принятия решений, когда возникают конфликты между мотивами. Парадигмы включают принудительную имитацию одной модели при игнорировании другой (подражание медведю, а не дракону), а также изменение визуальной организации, чтобы точно отразить логическую последовательность («тест циклов»; «отметь лишнее»). Эти конфликты заставляют детей изменять свое поведение/убеждения, чтобы приспосабливаться к нетипичным ситуациям.

\section{Topeltteadvuse ja topeltstimulatsiooni dialoogiline olemus: Peirce'i ja Võgotski implikatsioonid}

Artikli eesmärgiks on näidata Peirce’i topeltteadvuse möödapääsmatust abduktiivse arutlemise soodustamisel, nii et sisemise/välise dialoog toetab aimduste väärtuslikkust. Selliste dialoogivormidega kehtestatakse vaimne andmise ja võtmise väli, milles eriti rõhutatakse ja märgatakse uudseid tähendusi/efekte. Sellised tähelepanunihked tulenevad üllatavatest olukordadest vaatleja sisemistes tõlgenduspädevustes või välisteguritest (pildid, keelelised või žestisooritused). Nende märkide dialoogiline olemus kujundab ette operatsioone, mis pole mittedialoogilistena võimalikud - nendega kästakse, päritakse või pakutakse välja muudatusi heakskiidetud käitumistes/uskumustes kontekstides, milles välditakse propositsioonilisi/argumentatiivseid konflikte.

Uurimuses pakutakse välja eksperimentaalseid meetodeid, mõõtmaks, millal topeltteadvus (sisemise/privaatkõne kaudu) vahendab hüpoteeside tegemist. Võgotski motiivikonflikt neljal eristuval arengutasemel moodustab väljapakutavate eksperimentide vundamendi. Kavandid lähtuvad Võgotski 'topeltstimulatsiooni' paradigmadest, mis forsseerivad otsuste langetamise protsessi, kui esile kerkivad motiivikonfliktid. Paradigmade hulka kuulub ühe mudeli sunnitud matkimine, samas teist ignoreerides (matkida karu, mitte lohet) ning visuaalse korrastatuse muutmine, et õigesti kirjeldada loogilist järgnevust (tsüklite test, 'Märgi üleliigne'). Need konfliktid nõuavad, et lapsed muudaksid oma käitumist/uskumusi, et sobituda ebatüüpiliste olukordadega. 